\title{
Problem Psikis Lansia Dan Upaya Mengatasinya Melalui Bimbingan Keagamaan
}

\author{
Saepah $^{1 *}$, Aep Kusnawan ${ }^{2}$, Hajir Tajiri ${ }^{3}$ \\ 123Jurusan Bimbingan dan Konseling Islam, UIN Sunan Gunung Djati, Bandung \\ *Email : saepah.12@gmail.com
}

\begin{abstract}
ABSTRAK
Penelitian bertujuan untuk mengetahui keadaan psikis lansia, bimbingan keagamaan dan hasil bimbingan keagamaan untuk upaya mengatasi problem psikis lansia di Panti Sosial Tresna Werdha Budi Pertiwi. Penelitian ini menggunakan metode deskriptif dengan teknik pengumpulan data bertumpu pada observasi, wawancara dan dokumentasi. Hasil penelitian menunjukan bahwa: Keadaan psikis lansia disana kurang baik. Adapun bimbingan keagamaan yang dilakukan benar-benar berperan penting untuk upaya mengatasi problem psikis lansia. Dengan bimbingan keagamaan mereka bisa menyelesaikan berbagai permasalahan yang menimpa hidup mereka yang membuat hidup mereka tidak tenang. Dapat disimpulkan bahwa bimbingan keagamaan yang berikan kepada lansia untuk mengatasi problem psikisnya yaitu dengan metode ceramah, hapalan dan bed room. Dalam hal ini dapat dikatakan bahwa bimbingan keagamaan cukup baik dan lancar serta berdampak positif bagi lansia.
\end{abstract}

Kata Kunci: Lansia; Psikis Lansia; Bimbingan Keagamaan.

\section{ABSTRACT}

The study aims to find out the psychological state of the elderly, religious guidance and to find out the results of religious guidance to overcome the psychological problems of the elderly at the Tresna Werdha Budi Pertiwi Social Institution. This research uses descriptive method with data collection techniques based on observation, interviews and documentation. The results of the study show that the psychic condition of the elderly there is not good. The religious guidance carried out at the Tresna Werdha Budi Pertini Social Institution really plays an important role in efforts to overcome the psychological problems of the elderly. With religious guidance they can solve various problems that befall their lives that make their lives uneasy. It can be concluded that religious guidance is given to the elderly to overcome their psychological problems, namely the lecture method, memorization and bed room. In this case it can be said that religious guidance is quite good and smooth and has a positive impact on the elderly.

Keywords: Elderly; Psychic Elderly; Religious Guidance 
Saepah., A. Kusnawan., H. Tajiri.

\section{PENDAHULUAN}

Proses menua (aging) adalah proses yang alami disertai adanya penurunan kondisi fisik, psikologis maupun sosial yang saling berinteraksi satu sama lain. Keadaan itu cenderung berpotensi menimbulkan masalah kesehatan secara umum maupun kesehatan jiwa secara khusus pada lansia. penelitian menunjukan bahwa struktur keluarga nuclear family tidak memberikan tempat bagi para lanjut usia. Sebagian dari mereka hidup seorang diri di panti-panti wreda dan sebagian lagi hidup seorang diri ditemani binatang piaraannya. Mereka hidup dalam keterasingan, kesepian, isolasi sosial serta tidak tahu harus berbuat apa untuk mengisi masa tuanya. Banyak diantara mereka menunjukan berbagai gangguan kesehatan jiwa, antara lain depresi yang pada gilirannya menimbulkan rasa putus asa dan tindakan bunuh diri. (Hawari,1999:287)

Panti sosial Tresna Wredha Budi Pertiwi jalan Sancang No. 2 Bandung merupakan tempat penampungan lansia (lanjut usia) untuk membantu pemerintah dalam upaya penanggulangan penyandang masalah kesejahteraan sosial. Panti Sosial Tresna Wredha Budi Pertiwi mengadakan kegiatan-kegiatan yang positif sesuai dengan kemampuan dan kondisi mereka (lansia) sehingga mereka tetap dapat mengaktualisasikan potensi diri melalui aktivitas yang bermanfaat, kegiatan lainnya yaitu bimbingan keagamaan yang dapat menambah pengetahuan tentang agama untuk lebih mendekatkan diri kepada Allah SWT dan untuk mengembangkan potensi dirinya sehingga mereka mampu menyelesaikan masalah-masalah yang dihadapinya.

Panti sosial Tresna Wredha Budi Pertiwi senantiasa mengadakan kegiatankegiatan yang positif yang mana kegiatan yang dilakukannya sesuai dengan kemampuannya, minat dan bakat mereka (lansia) sehingga mereka dapat mengaktualisasikan potensi diri melalui aktivitas yang bermanfaat. Kegiatan lainnya yaitu berupa bimbingan keagamaan. Kegiatan bimbingan keagamaan ini bertujuan selain untuk menambah pengetahuan tentang agama, untuk lebih mendekatkan diri kepada Allah SWT dan untuk mengembangkan potensi dirinya sehingga mereka mampu menyelesaikan masalah yang dihadapinya. Serta senantiasa lebih termotivasi untuk dapat melakukan aktivitas yang positif di sisa hidupnya.

Bimbingan keagamaan di Panti Sosial Tresna Wredha Budi Pertiwi dilakukan secara bertahap. Pembimbing melakukan persiapan sebelum melaksanakan bimbingan keagamaan dengan menyiapkan materi yang akan disampaikan. Bimbingan dilaksanakan setiap hari jum'at dan sabtu dengan durasi waktu satu jam di mushola panti. Kendala yang dihadapi pembimbing pada lanjut usia adalah kondisi fisik yang telah menurun, daya ingat dan konsentrasi yang sudah mulai lambat karena faktor udzur.

Dengan fenomena di atas, peneliti bermaksud untuk mengetahui problem 
psikis lansia dan penanganannya melalui bimbingan keagamaan di Panti Sosial Tresna Wredha Budi Pertiwi Kota Bandung agar mereka dapat melaksanakan kegiatan-kegiatan pengamalan ibadah dengan baik dan mampu menyelesaikan permasalah dirinya walaupun dengan segala keterbatasan secara fisik dan daya pikir yang dimiliki oleh lansia. Peneliti membuat beberapa pertanyaan sebagai berikut: pertama, keadaan psikis lansia, 1) bagaimana perasaan lansia ketika pertama kali masuk panti sosial? 2) bagaimana keadaan lansia setelah berada di panti sosial? 3) apa saja ragam masalah yang dihadapi lansia di panti sosial? 4) bagaimana lansia menyelesaikan permasalahan yang sedang dihadapinya? 5) bagaimana tingkat kemampuan lansia menyelesaikan masalah yang dihadapinya?

Kedua, Bimbingan keagamaan, 1) siapa saja yang melakukan bimbingan keagamaan? (syarat, kemampuan), 2) materi apa saja yang disampaikan pada proses bimbingan keagamaan? (apa alasannya, tujuannya), 3) metode apa yang digunakan dalam proses bimbingan keagamaan? Alasannya, 4) media dan fasilitas apa saja yang digunakan? Alasannya, 5) bagaimana minat keagamaan lansia setelah adanya pelaksanaan bimbingan keagamaan? faktor apa, 6) bagaimana proses terlaksananya bimbingan keagamaan lansia? Tahapan, 7) keluhan apa saja yang sering disampaikan oleh lansia kepada pembimbing keagamaan?

Berdasarkan pertanyaan penelitian diatas dapat dirumuskan masalah pokok yang menjadi objek kajian penelitian, sebagai berikut: 1) bagaimana keadaan psikis lansia di Panti Sosial Tresna Wredha Budi Pertiwi Kota Bandung? 2) bagaimana bimbingan keagamaan dalam upaya mengatasi problem psikis lansia di Panti Sosial Tresna Wredha Budi Pertiwi Kota Bandung? 3) bagaimana hasil bimbingan keagamaan mengenai problem psikis lansia dan upaya mengatasinya melalui bimbingan keagamaan di Panti Sosial Tresna Wredha Budi Pertiwi Kota Bandung?

Metode yang digunakan dalam penelitian ini yaitu metode desriptif. Metode deskriptif itu prosedur pemecahan masalah yang diselidiki dengan menggambarkan atau melukiskan keadaan subjek atau objek penelitian (seseorang, lembaga, masyarakat, dll). Alasan penggunaan metode tersebut karena penulis akan menggambarkan fenomena yang terjadi dilokasi penelitian secara apa adanya berdasarkan observasi, wawancara dan studi dokumentasi. Hal ini sesuai dengan karakter metode deskriptif yang berusaha menggambarkan tentang metode bimbingan keagamaan untuk meningkatkan kualitas ibadah lansia. Teknik pengumpulan data melalui observasi lansung dilakukan dengan mengamati berbagai kegiatan dan proses bimbingan keagamaan yang dilaksanakan di Panti Sosial Tresna Wredha Budi Pertiwi. Untuk mendapatkan data yang lebih detail dan lengkap, penelitian ini akan melakukan wawancara langsung dengan sumber data yaitu para pembimbing keagamaan dan pengelola Panti Sosial Tresna Wredha Budi Pertiwi serta beberapa lansia. 
Saepah., A. Kusnawan., H. Tajiri.

\section{LANDASAN TEORITIS}

Teori yang dijadikan landasan dalam penelitian ini adalah teori bimbingan, keagamaan dan psikis lansia (lanjut usia). Bimbingan secara harfiah, merupakan penerjemahan yang diambil dari bahasa Inggris yaitu "guidance" yang berasal dari kata kerja (to) guide, yang artinya menuntun, mempedomani, menjadi petunjuk jalan, mengemudikan. Adapun pengertian bimbingan yang lebih formulatif adalah bantuan yang diberikan kepada kepada individu agar dengan potensi yang dimiliki mampu mengembangkan diri secara optimal dengan jalan memahami diri, memahami lingkungan, mengatasi hambatan guna menentukan rencana masa depan yang lebih baik (Umar dan Sartono, 1998:9)

Bimbingan merupakan proses pemberian bantuan yang terus menerus dari seorang pembimbing yang telah dipersiapkan kepada individu yang membutuhkannya dalam rangka mengembangkan seluruh potensi yang dimilikinya secara optimal dengan menggunakan berbagai macam media dan teknik bimbingan dalam suasana yang normatif agar tercapai kemandirian sehingga individu dapat bermanfaat bagi dirinya dan lingkungannya (Hallen, 2002:9).

Dari definisi bimbingan di atas dapat ditarik kesimpulan bahwa bimbingan merupakan pemberian bantuan yang bersifat psikis yang dilakukan secara terus menerus dan sistematis kepada individu agar individu tersebut sanggup memecahkan masalah yang dihadapinya, memahami dirinya, mengarahkan dirinya dan mampu menyesuaikan diri dengan lingkungannya, baik keluarga maupun masyarakat. Menurut James Martinean mengartikan bahwa: "agama adalah kepercayaan kepada Tuhan yang selalu hidup yakni kepada jiwa dan kehendak Ilahi yang mengatur alam semesta dan mempunyai hubungan moral dengan umat manusia" (Rahmat, 2003:50).

Pengertian agama secara umum yaitu suatu sistem credo (tata keimanan dan keyakinan atas adanya suatu yang mutlak di luar manusia. Suatu sistem yang ritus (tata cara peribadatan) kepada yang dianggap mutlak, yang mengatur manusia dengan alam. Pengertian agama secara khusus yang dimaksud dengan agama Islam adalah: (1) wahyu yang diturunkan oleh Allah kepada Rasul-Nya untuk disampaikan kepada manusia sepanjang masa dan setiap persada. (2) suatu sistem akidah dan tata aturan akidah yang mengatur segala perikehidupan dan penghidupan manusia dengan Tuhan-Nya maupun hubungan manusia dengan manusia juga hubungan manusia dengan alam lainnya seperti nabati, hewani dan lain-lain. (3) bertujuan keridhaan Allah SW'T, rahmat bagi segenap alam, kebahagiaan di dunia dan akhirat dan pada garis besarnya terdiri dari Aqidah dan Syari'ah (yang meliputi ibadah dalam arti khas dan muamalah dalam arti luas). (Anshari, 1991:11).

Berdasarkan uraian di atas dapat diambil suatu kesimpulan bahwa agama 
Problem Psikis Lansia Dan Upaya Mengatasinya Melalui Bimbingan Keagamaan adalah ajaran dari Tuhan atau hasil renungan manusia terkandung dalam kitab suci yang turun temurun diwariskan oleh suatu generasi ke generasi dengan tujuan untuk memberi tuntunan dan pedoman hidup bagi manusia agar mencapai kebahagiaan di dunia dan akhirat. Sedangkan keagamaan berarti sesuatu yang berkaitan dengan agama yaitu sesuatu yang berkaitan dengan kepercayaan, keyakinan, kepatuhan terhadap Tuhan dengan kata lain keagamaan itu merupakan sesuatu yang mengandung sifat-sifat agama. Kegiatan keagamaan berarti kegiatankegiatan yang bernafaskan agama, dalam artian kegiatan yang mengandung sifatsifat, nilai-nilai atau norma-norma dan kaidah agama.

Jadi, Bimbingan keagamaan adalah usaha pemberian bantuan kepada seseorang yang mengalami kesulitan baik lahir maupun bathin yang menyangkut kehidupan di masa kini dan masa mendatang. Bantuan tersebut berupa pertolongan di bidang mental dan spiritual, dengan maksud agar orang yang bersangkutan mampu mengatasi kesulitannya dengan kemampuan yang ada pada dirinya sendiri melalui dorongan dari kekuatan iman dan taqwa kepada Allah SWT. (Arifin 1994: 2).

Bimbingan keagamaan membantu manusia untuk memelihara dan mengembangkan sifat-sifat yang telah diajarkan oleh agama. Bimbingan keagamaan juga salah satu jalan untuk menjadikan manusia mempunyai makna baik bagi dirinya maupun lingkungannya. Bimbingan dalam pelaksanaannya dilakukan secara terus menerus dan sistematis oleh pembimbing agar yang di bimbing memiliki kualitas kemandirian yang dipengaruhi oleh aspek keagamaan. Bimbingan keagamaan islami adalah proses pemberian bantuan terhadap individu agar dalam kehidupan keagamaannya senantiasa selaras dengan ketentuan dan petunjuk Allah, sehingga dapat mencapai kebahagiaan hidup di dunia dan akhirat. (Faqih, 2001:4).

Dengan demikian dapat disimpulkan bahwa bimbingan keagamaan adalah cara yang ditempuh oleh pembimbing dalam rangka mendekati masalah yang timbul dari pelaksanaan bimbingan keagamaan sehingga dapat menghasilkan tujuan yang akan dicapai.

Muhibbin Syah (2001:54) mengemukakan bahwa masa tua (old age) yang dalam istilah psikologi disebut "senescence" adalah fase terakhir kehidupan manusia. Masa ini berlangsung antara 60 tahun sampai berhembusnya nafas terakhir (akhir hayat). Pendapat tersebut sesuai dengan batasan usia yang di utarakan oleh WHO yang menyatakan bahwa usia tua dimulai dari usia 60 tahun ke atas, walaupun ada pendapat yang mengatakan bahwa lansia adalah orang yang berumur 55 tahun ke atas. Di Negara-negara maju, yang dimaksudkan dengan lanjut usia adalah mereka yang telah menjalani siklus kehidupan di atas usia 65 tahun. Di dalam gerontology (ilmu spesialis yang mempelajari lanjut usia), lanjut usia di bagi dalam dua golongan, yaitu yang dinamakan "young old" (65-74 tahun) dan "old-old” (di atas 75 tahun) (Hawari, 1999: 289). 
Saepah., A. Kusnawan., H. Tajiri.

Masa tua biasanya ditandai oleh perubahan-perubahan kemampuan motorik yang semakin merosot, diantara perubahan tersebut adalah menurunnya kekuatan otot yang menyangkut seluruh tubuh. Oleh karena itu, pada umumnya orang tua lebih cepat merasa lelah untuk mengembalikan kesegaran tubuhnya dari kelelahan, ia memerlukan waktu yang lebih lama daripada ketika ia masih muda. Berbagai upaya ditempuh orang, baik dari segi fisik, mental, sosial dan spiritual (agama) adalah dengan maksud untuk memperlambat proses penuaan sel-sel organ tubuh, sehingga fungsinya dapat bertahan lama yang pada gilirannya usia pun bertambah panjang.

Pada usia 65 tahun (masa tua) manusia akan menghadapi sejumlah permasalahan. Permasalahan pertama adalah penurunan kemampuan fisik yang disebabkan oleh kemunduran pada organ tubuh; ukuran sel mengecil, komposisi sel pembentuk jaringan baru juga berkurang bahkan terhenti sama sekali, sehingga menyebabkan kekuatan fisik berkurang (degeneratif), aktivitas menurun, sering mengalami gangguan kesehatan yang menyebabkan mereka kehilangan semangat. Problem utama pada wanita usia lanjut adalah rasa kesepian dan kesendirian, rasa kehilangan (loss) gejala utama pada usia lanjut. (Hawari, 1999:293).

Permasalahan muncul karena bukan hanya rata-rata lansia mengidap lebih satu jenis penyakit, namun proses pengobatannya berlangsung sepanjang sisa hidupnya. Masalahnya siapa yang merawatnya, siapa yang membiayai pengobatan tersebut, masalah ini akan membawa konsekuensi panjang sehingga muncul pemikiran bahwa mereka berada pada sisa-sisa umur menunggu datangnya kematian.

\section{HASIL DAN PEMBAHASAN}

Panti Sosial Tresna Wredha Budi Pertiwi didirikan pada tanggal 9 November 1948 oleh organisasi budi istri yang pada awalnya belum diberi nama Panti Sosial Tresna Wredha Budi Pertiwi. Didirikannya panti ini karena tragedi bandung lautan api, pada tragedi tersebut banyak orang tua atau lansia yang kehilangan keluarga, anak, suami, tempat tinggal bahkan harta merekapun musnah, yang akhirnya hidup mereka sebatang kara dan terlantar. Melihat fenomena tersebut organisasi budi istri bekerja sama dengan PMI (Palang Merah Indonesia) mempunyai inisiatif untuk menyelamatkan para lansia dengan menampung mereka di sebuah rumah yang tidak dipakai oleh pemiliknya.

Rumah tersebut terletak di Lengkong Besar, namun beberapa tahun kemudian rumah tersebut diambil alih kembali oleh pemiliknya. Organisasi budi istri beserta PMI kebingungan karena tidak ada tempat untuk menampung para orang tua atau lansia tersebut. Akhirnya organisasi budi istri mengadu ke Jakarta kepada menteri sosial untuk meminta kebijakan pemerintah guna melindungi para lansia yang hidupnya terlantar. Kemudian dibangunlah sebuah panti untuk menampung para lansia yang terlantar dan pada tahun 1957 panti tempat 
Problem Psikis Lansia Dan Upaya Mengatasinya Melalui Bimbingan Keagamaan penampungan lansia terlantar itu diberi nama oleh Presiden Republik Indonesia yang pertama (Soekarno) dengan nama Panti Sosial Tresna Wredha Budi Pertiwi.

Masalah terlantarnya para lansia merupakan masalah yang pelik dan mengkhawatirkan bagi kita semua, mereka yang seharusnya hidup tenang dan senang dimasa tuanya menghabiskan sisa umurnya untuk beribadah kepada Allah SWT tetapi mereka para lansia yang terlantar bukan mendapatkan ketenangan dan kesenangan melainkan kesengsaraan yang mereka alami. Oleh karena itu tujuan berdirinya Panti Sosial Tresna Wredha Budi Pertiwi adalah untuk memelihara atau menyantuni lansia wanita yang tidak mampu, tidak mempunyai anak, hidup terlantar atau diterlantarkan oleh keluarganya, dan dengan tujuan tersebut memiliki maksud diantaranya: 1) meningkatkan gairah hidup, hidup ceria dan bahagia dimasa tua, 2) menghilangkan perasaaan bahwa mereka dikucilkan, 3) menumbuhkan perasaan bahwa mereka masih berguna melalui hidup gotong royong, saling menolong diantara sesama penghuni. Merasakan secercah kebahagiaan dan ketenangan hidup, sebelum maut menjemputnya.

Kelengkapan saranan yang dimiliki Panti Sosial Tresna Wredha Budi Pertiwi adanya organisasi yang lengkap untuk mencapai tujuan yang diharapkan. Hal ini juga diterapkan dalam pelaksanaan fungsi dan tata kerja lembaga di Panti, sebagai berikut:

Tabel 1.

Pengurus Harian

\begin{tabular}{lll}
\hline Nama & Jenis Kelamin & Jabatan Pengurus \\
\hline Ny. Hj. Nia Kurniasih & Perempuan & Ketua \\
Ny. Ai Djoewarsa & Perempuan & Wakil Ketua \\
Yetti Anjar Pg. & Perempuan & Sekretaris \\
Ny. Tiktik Kartika & Perempuan & Bendahara I \\
Ny. Hj. Early Rahmawati & Perempuan & Bendahara Ii \\
Ny. Hj. Sri Hartati & Perempuan & Pemeriksa \\
\hline
\end{tabular}

Sumber: Dokumentasi Panti Sosial Tresna Werdha Budi Pertiwi, dikutip bulan September 2016 
Saepah., A. Kusnawan., H. Tajiri.

Tabel 2.

Seksi-seksi di Panti Sosial Tresna Werdha Budi Pertiwi

\begin{tabular}{|c|c|c|c|}
\hline \multirow[t]{2}{*}{ Nama } & \multicolumn{2}{|c|}{ Jenis Kelamin } & Jabatan \\
\hline & Ny. Hj.Pupu & Perempuan & Kerohanian \\
\hline & Ny. Titi Hasanah & Perempuan & Olahraga \\
\hline & Dr. Sanny & Perempuan & Kesehatan \\
\hline & $\mathrm{Hj} . \mathrm{Ai}$ & Perempuan & Pendidikan \\
\hline
\end{tabular}

Sumber: Dokumentasi Panti Sosial Tresna Werdha Budi Pertiwi, dikutip bulan September 2016

Tabel 3.

Nama-nama karyawan di Panti Sosial Tresna Werdha Budi Pertiwi

\begin{tabular}{lll}
\hline Nama & Jenis Kelamin & $\begin{array}{l}\text { Jabatan } \\
\text { Pengurus }\end{array}$ \\
\hline Cecep Tosin Maulana & Laki-Laki & Pembantu Umum \\
David & Laki-Laki & Pengemudi \\
O. Dedi Sumadi & Laki-Laki & Kebersihan \\
Djuju Djubaedah & Perempuan & Juru Masak \\
Kartinah & Perempuan & Perawat Lansia \\
Anah & Perempuan & Perawat Lansia \\
Etjin Kuraesin & Perempuan & Perawat Lansia \\
Ela & Perempuan & Perawat Lansia \\
Titin & Perempuan & Perawat Lansia \\
\hline
\end{tabular}

Sumber: Dokumentasi Panti Sosial Tresna Werdha Budi Pertiwi, dikutip bulan September 2016

Panti Sosial Tresna Wredha Budi Pertiwi mempunyai tanggung jawab terhadap perawatan dan pemeliharaan para lansia, baik itu fisik maupun mental. Pertama kesehatan, untuk menjamin kesehatan para lansia ditangani oleh seksi kesehatan yang di damping oleh seorang perawat. Pemberian obat dan perlengkapan kesehatan dilakukan oleh seksi kesehatan Panti Sosial Tresna Wredha Budi Pertiwi. Panti itu juga bekerja sama dengan Dinas Kesehatan Kotamadya melalui Puskesmas Talaga Bodas dalam waktu satu bulan sekali dokter beserta dua orang perawat datang ke panti untuk memeriksa kesehatan para lansia dan memberi pengobatan, yang sakit berat dengan rujukan dari Puskesmas di 
bawa ke RSHS Bandung untuk mendapatkan perawatan lebih lanjut.

Kedua makanan, makanan yang di sajikan di Panti Sosial Tresna Wredha Budi Pertiwi ini sangat memenuhi kebutuhan kalori serta gizi yang cukup. Makanan yang diberikan 3 kali sehari, yaitu pagi jam 07.00, siang 10.00 dan sore jam 15.00. Para penghuni lansia adakalanya mendapat kiriman dari para donator dan dari keluarganya yang masih memiliki keluarga. Ketiga pakaian, pakaian yang diperoleh para penghuni Panti Sosial Tresna Wredha Budi Pertiwi ini berasal dari para donator dan dari sumbangan yang layak pakai. Adapun kebersihan pakaian para lansia dibersihkan atau di cuci sendiri bagi lansia yang masih mampu dan bagi lansia yang sudah tidak bisa membersihkan pakainnya sendiri di bantu oleh para pembimbing atau pengurus panti.

Tugas pokok Panti Sosial Tersna Wredha Budi Pertiwi Bandung adalah melaksanakan pemeliharaan dan pembinaan para lansia baik secara fisik maupun mental serta melakukan perlindungan terhadap hak asasi manusia dalam keseimbangan dan kepentingan umum. Proses pembinaan para lansia ini ditunjang oleh pendidikan tertentu yaitu agama, bimbingan rohani islam dan keterampilan. Program pembinaan ini diberikan dalam rangka mengantarkan para lansia agar senantiasa beriman dan bertaqwa kepada Allah SWT sehat jsamani rohani dan bahagia sejahtera serta mengantarkan para lansia menuju khusnul khatimah.

Jumlah lansia yang tercatat pada bulan September 2016 sebanyak 32 orang yang rata-rata umurnya di atas 60 tahun dan semuanya berjenis kelamin wanita dan beragama islam. Mereka berasal dari berbagai daerah yang berbeda-beda dengan latar belakang pendidikan yang sangat minim. Pada umumnya ciri lansia di Panti Sosial Tresna Werdha Budi Pertiwi secara fisik banyak mengalami kemunduran dan mengalami perubahan yaitu badan sudah mulai membungkuk, gigi tanggal, rambut sudah mulai putih, fungsi tubuh yang sudah mulai menurun seperti alat indera pendengaran dan penglihatan yang sudah mulai tidak berfungsi secara normal.

Secara psikis sudah mengalami kemunduran yang ditandai dengan daya ingat yang sudah mulai berkurang dan mudah lupa, mudah tersinggung antara satu dengan yang lainnya sehingga sering bertengkar, mudah sedih dan malasa mengikuti kegiatan. Dan keberagamaan para lansia di Panti Sosial Tresna Werdha Budi Pertiwi, setelah mendapatkan bimbingan keagamaan dari pembimbing sehingga mereka lebih banyak mendekatkan diri kepada Allah SWT dan saling mencintai antara sesama.

\section{Keadaan Psikis Lansia Di Panti Sosial Tresna Wredha Budi Pertiwi}

Secara psikis ditandai dengan tidak akan lamanya jika berpikir terlalu lama dibandingkan pada masa muda. Masalah-masalah lansia yang sering terjadi di Panti Sosial Tresna Werdha Budi Pertiwi yaitu sering sakit-sakitan, sering bertengkar sesama penghuni, keadaan fisik yang lemah dan tidak berdaya sehingga 
Saepah., A. Kusnawan., H. Tajiri.

harus tergantung pada orang lain, sebagian penghuni belum bisa mengaji, kesepian dikarenakan rindu kepada keluarga.

Dalam menyelesaikan permasalahan yang dihadapi lansia, seperti nenek Rochimah ketika mendapatkan masalah beliau menjawab "ketika saya rindu keluarga, saya hanya bisa mendoakan mereka supaya sehat. Kalau lagi bertengkar dengan teman, saya ngobrol dengan teman yang lain atau kepada pembimbing keagamaan bertanya apa yang harus saya lakukan supaya saya baikan lagi, mereka memberi saya wejangan dan harus saling menghargai sesama penghuni panti”

Secara keberagamaan para lansia di Panti Sosial Tresna Werdha Budi Pertiwi setelah mendapatkan bimbingan keagamaan mereka lebih banyak mendekatkan diri kepada Allah SWT dan saling mencintai antar sesama. Perubahan yang terjadi pada lansia di Panti Sosial Tresna Werdha Budi Pertiwi sedikit ataupun banyak akan mempengaruhi hasil bimbingan keagamaan. Oleh sebab itu dibutuhkan ketekunan dan kesabaran seorang pembimbing untuk membimbing para lansia dan menyampaikan materi dengan cara berulang-ulang.

Bimbingan keagamaan adalah usaha pemberian bantuan kepada seseorang yang mengalami kesulitan baik lahir maupun bathin yang menyangkut kehidupan di masa kini dan masa mendatang. Bantuan tersebut berupa pertolongan di bidang mental dan spiritual, dengan maksud agar orang yang bersangkutan mampu mengatasi kesulitannya dengan kemampuan yang ada pada dirinya sendiri melalui dorongan dari kekuatan iman dan taqwa kepada Allah SWT (Arifin, 1994:2)

\section{Bimbingan Keagamaan Dalam Upaya mengatasi Problem Psikis Lansia}

Berdasarkan hasil wawancara dengan Ibu Hj. Pupu pada tanggal 4 November 2016 selaku pembimbing keagamaan di Panti Sosial Tresna Werdha Budi Pertiwi bahwa bimbingan keagamaan dilakukan $2 \mathrm{x}$ seminggu yaitu hari jumat dan sabtu. Metode yang digunakan dalam bimbingan keagamaan ini menurut $\mathrm{Ibu} \mathrm{Hj}$. Pupu yaitu dengan menggunakan metode ceramah, hapalan, dan bed room.

Metode ceramah digunakan dalam bimbingan keagamaan yang sifatnya kelompok, metode ceramah ini biasanya dilakukan setiap hari sabtu pagi setelah para lansia mengikuti materi bimbingan membaca Al-Qur'an dan shalawat serta do'a. Pembimbing yang memberikan materi ceramah ini adalah Ibu $\mathrm{Hj}$. Pupu.

Pertama, materi akidah disampaikan oleh pembimbing untuk memperkuat keimanan dan keyakinan wanita lanjut usia terhadap ke Esaan Allah SWT, malaikat-malaikat-Nya, kitab-kitab-Nya, rasul-rasul-Nya, percaya (mengimani) pada takdir yang baik maupun buruk yang datang dari Allah SWT. Kedua, materi ibadah mahdhah yakni ibadah langsung dengan Allah SWT, sangat dititik tekankan pada rukun Islam yakni syahadat, shalat (wajib dan sunat), zakat, shaum (wajib dan sunat), dan menunaikan ibadah haji ke Baitullah. Materi ibadah ghair mahdhah yakni ibadah tersebut disampaikan dengan sesama manusia (hablum minannas/ muamalah), meliputi jual beli, shadaqah, gadai, sewa menyewa dan sebagainya. 
Tujuan pemberian materi ibadah adalah agar para lansia dalam menjalankan ibadahnya sesuai dengan ketentuan Allah SWT dalam rangka mencari keridhoanNya. Ketiga, materi istighosah (meminta pertolongan kepada Allah SWT) sangat dianjurkan oleh agama, lebih-lebih ketika sedang menghadapi atau mengalami permasalahan yang besar dan jalan yang ditempuh sangat sulit. Pada saat itu meminta pertolongan kepada Allah SWT sangat diperlukan. Keempat, materi akhlak disampaikan oleh pembimbing agar para lansia senantiasa berakhlakul karimah (berperilaku baik) kepada keluarganya, teman sejawatnya dan kepada orang-orang yang lebih muda darinya. Dalam memberikan materi ini, pembimbing selalu mengatakan lansia agar senantiasa tumbuh dengan dirinya sikap saling menyayangi, menghormati dan menghargai orang-orang yang ada disekelilingnya, selain itu pembimbing juga mengingatkan para lansia agar menghindari atau menjauhi akblakus syyiah (berperilaku buruk) kepada orangorang disekelilingnya.

Selain metode bersifat ceramah ada juga yang bersifat obrolan yang tidak formal, biasanya dalam obrolan ini lansia mengutarakan masalah-masalah yang dihadapi seputar kehidupannya, mereka merasa kesepian dan kurang diperhatikan oleh keluarganya. Dalam menanggapi permasalah itu, pembimbing lebih bersifat bijaksana dengan mengarahkan obrolan pada hal-hal yang positif serta berusaha untuk mencari jalan keluar (problem solving) dari permasalahan tersebut, sehingga tumbuh kepercayaan dalam diri mereka untuk mneghadapi dan menjalankan hidup dengan baik dan bijak serta senantiasa "positif tbinking". Metode ini terus dibina dan dikembangkan mengingat masalah lansia sangat beragam, diantara masalah yang berhubungan dengan kehidupan keagamaan dan keluarga serta masalah lainnya yang membutuhkan bantuan pembimbing berupa arahan-arahan untuk menangani permasalahan tersebut.

Agar materi ceramah mudah dipahami dan dimengerti oleh lansia, maka pemimbing mengambil langkah-langkah sebagai berikut: 1) sebelum melaksanakan ceramah, terlebih dahulu beberapa waktu sebelumnya pembimbing mempersiapkan materi yang akan diceramahkan dengan cara menelaah dan mempelajari materi yang akan dibahas dalam ceramah, 2) secara rutin pembimbing memulai ceramahnya dengan membaca Al-Qur'an atau hadis sebagai rujukan untuk menjelaskan materi ceramah yang akan disampaikan, 3) pembimbing berusaha untuk menjelaskan maksud dan tujuan dari ayat tersebut dengan menyertakan contoh-contoh yang relevan dengan materi yang disampaikan.

Penyampaiannya menggunakan bahasa yang ringan sesuai dengan kemampuan dan pola pikir lansia, agar materi tersebut mudah dimengerti dan dipahami oleh mereka, 4) untuk menghndari kejenuhan dalam ceramah maka pembimbing menyisihkan humor-humor yang menghibur sebagai selingan dengan tidak menghilangkan esensi dan ceramah yang bersifat mendidik, 5) 
Saepah., A. Kusnawan., H. Tajiri.

setelah materi ceramah dianggap cukup untuk disampaikan, maka pembimbing menyimpulkan materi ceramah dalam bentuk poin-poin. Hal tersebut untuk mengingatkan kembali materi ceramah pada mereka yang mudah lupa.

Metode ceramah ini diterapkan pada lansia, karena dengan mudah pembimbing bisa sekaligus membimbing banyak orang. Namun dibutuhkan ketekunan dan kesabaran pembimbing dalam menyampaikan materi ceramah yang harus dilakukan secara berulang-ulang mengingat lansia mudah lupa dan tingkat pemahaman mereka terhadap materi relatif lambat.

Adapun media dalam melaksanakan bimbingan keagamaan di Panti Sosial Tresna Wredha Budi Pertiwi ini benar-benar terfasilitasi. Adanya mushola yang digunakan selain untuk shalat juga untuk melakanakan bimbingan keagamaan, AlQur'an serta berbagai macam kumpulan doa-doa yang dibagikan kepada seluruh penghuni panti untuk dihapal dan diaplikasikan sehari-hari.

Menurut pengakuan dari oma wahyu selaku KM dari penghuni Panti Sosial Tresna Wredha Budi Pertiwi, beliau menjelaskan jika bimbingan keagamaan yang dilakukan di Panti Sosial Tresna Wredha Budi Pertiwi betul-betul berperan penting. Karena dengan agama mereka bisa saling menghargai dan menghormati antar sesama, selain itu juga mereka bisa mengendalikan emosi mereka ketika mereka marah ataupun sedih dengan cara banyak berdzikir. Selain itu juga kami selalu mengingatkan kepada mereka untuk selalu rajin beribadah kepada Allah SWT. "karena ibadah itu dilakukan untuk bekal kita di akhirat", tutur oma Wahyu.

Tujuan bimbingan keagamaan Islam sebagai berikut: 1) membantu individu atau kelompok individu mencegah timbulnya masalah dalam kehidupan keagamaan, 2) membantu individu memecahkan masalah yang berkaitan dengan kehidupan keagamaannya, 3) membantu individu memelihara situasi dan kondisi kehidupan keagamaan dirinya yang telah baik agar tetap baik dan atau menjadi lebih baik (Fakih, 2001:62-63).

\section{Hasil Bimbingan Keagamaan Untuk Mengatasi Problem Psikis Lansia}

Untuk mendapatkan hasil bimbingan keagamaan terhadap lansia, disini penulis melakukan pengambilan sampel dengan memakai tehnik pengambilan sampling purposive dengan arti bahwa dalam pengambilan sampel disini penulis memilih sampel yang memenuhi kriteria-kriteria tertentu yang memenuhi dalam proses penelitian. Yang mana dalam penelitian ini penulis memilih beberapa sampel yang telah ditentukan oleh penulis berdasarkan rekomendasi dari pihak panti sendiri. Adapun yang menjadi kriteria untuk sampel penulis disini yaitu: 1) beragama islam, 2) benar penghuni Panti Tresna Wredha Budi Pertiwi (bukan pengurus panti), 3) sehat jasmani, 4) mampu berkomunikasi dengan baik

Berdasarkan kriteria yang ada diatas dan berbagai pertimbangan dari pengurus panti maka dapat sampel sebanyak 15 orang dari populasi yang berjumlah 32 orang. Berdasarkan hasil penelitian yang dilakukan pada tanggal 5 
September 2016 dengan mewawancarai 15 orang penghuni panti diperoleh hasil sebagai berikut.

Dalam proses pelaksanaan bimbingan keagamaan yang ada di Panti Sosial Tresna Wredha Budi Pertiwi ini mereka mengaku sangat baik dengan alasan bahwa bimbingan keagamaan sangat membantu mereka dalam menghadapi permasalahan hidup dan mereka tahu akan peranan keagamaan itu sangat penting bagi hidup mereka. Oleh karena itu mereka selalu mengikuti serangkaian kegiatan bimbingan keagamaan yang dilaksanakan 2x dalam seminggu yaitu pada hari jumat dan sabtu pagi. Adapun materi yang diberikan dalam melaksanakan kegiatan keagamaan ini mencakup aqidah, akhlak dan tata cara beribadah serta menjelaskan manfaat beribadah di hari tua. Selain itu juga setiap kegiatan keagamaan yang dilakukan mereka selalu melakukan tawasul kepada orang-orang yang sudah meninggal dan orang yang ingin di doakan. Dorongan yang menggugah hati mereka untuk mengikuti kegiatan keagamaan ini yaitu mereka sadar akan kewajiban mereka sebagai umat Islam untuk senantiasa beribadah kepada Allah dengan cara rajin shalat dan melaksanakan amalan-amalan lain dan jika mereka tidak mengikuti bimbingan keagamaan ini, hal itu dikarenakan mereka sedang sakit saja.

Metode bimbingan keagamaan yang dilakukan oleh pembimbing dengan menggunakan metode ceramah, hapalan, dan kunjungan ke kamar. Metode hapalan ini dilakukan bagi para penghuni lansia yang belum mengetahui tentang doa-doa shalat terlebih niat shalat, surat Al-Fatihah dan doa shalat. Oleh karena itu dalam kegiatan bimbingan keagamaan pembimbing selalu melakukan hapalan kepada para lansia dengan cara diberi contoh terlebih dahulu bagaimana cara menghapal bacaan shalat dan doa yang tartil dan benar. Selain di bimbing oleh pembimbing antar penghuni senantiasa membantu penghuni lainnya untuk mengetes hapalan doa yang baru dihapalkan.

Adapun perubahan-perubahan yang terjadi pada lansia setelah mereka masuk kea Panti Sosial Tresna Wredha Budi Pertiwi mereka mengaku sangat berbeda, tinggal di Panti Sosial Tresna Wredha Budi Pertiwi ini membuat hidup mereka lebih berwarna dan mempunyai banyak teman yang seusia dengan mereka. Di Panti Sosial Tresna Wredha Budi Pertiwi ini mereka banyak belajar tentang segala hal yang tidak mereka tahu ketika mereka hidup di daerah asal mereka seperti belajar mengenal sifat antar satu dengan yang lain, belajar sabar dalam menghadapi masalah (baik masalah dengan teman penghuni panti maupun masalah diri sendiri), belajar untuk saling mengingatkan dan belajar untuk bertaubat bersama-sama karena mereka menyadari bahwa hidup mereka didunia hanya sebentar dan mereka juga tidak tahu kapan ajal datang menjemput mereka. Oleh karena itu mereka saling mengingatkan untuk hidup rukun dan rajin beribadah untuk bekal mereka di akhirat. Dan mereka juga senantiasa selalu bersemangat untuk mengikuti setiap kegiatan yang ada di Panti Sosial Tresna 
Saepah., A. Kusnawan., H. Tajiri.

Wredha Budi Pertiwi ini seperti senam pagi, bimbingan keagamaan, kesenian, dan seni menjahit. Hal itu mereka lakukan dengan penuh semangat dan tanpa paksaan. Menurut pengakuan dari salah satu penghuni panti yang penulis wawancara yaitu nenek Rochimah yang ketika ditanya apakah nenek selalu mengikuti kegiatan yang ada di Panti Sosial Tresna Wredha Budi Pertiwi ini beliau senantiasa menjawab "ia, nenek selalu ikut kegiatan yang ada di panti ini biar tidak bosen diam terus dan biar tidak cepet pikun, dan kalau badan kita digerakin nantinya bisa sehat" tutur nenek Rochimah.

Adapun pengakuan lain yang disampaikan oleh penghuni panti ketika ditanya mengenai bagaimana peranan pembimbing keagamaan yang ada di Panti Sosial Tresna Werdha Budi Pertiwi bagi kehidupan nenek, nenek Mimi dengan semangat menjawab "sangat berperan penting de, karena ilmu agama itu benarbenar bekal kita untuk ke akhirat. Terlebih disini kan suka ada pengajian rutin yang dilakukan setiap minggunya, disana kami selalu melakukan tawasulan kepada orang-orang yang sudah meninggal, selalu mendoakan diri kita sendiri dan orang lain juga serta selalu melakukan dzikir bersama dan hal itu membuat hati nenek senang, tenang dan damai, jadi semua pikiran yang membuat jiwa nenek tidak enak itu jadi hilang" tutur nenek Mimi, nenek Cucu dan nenek Sukanah.

Berdasarkan hasil wawancara dan observasi lapangan yang dilakukan oleh penulis yang dimulai dari bulan September sampai November 2016 penulis memperoleh informasi dan pengetahuan tentang problem psikis lansia dan penanganannya melalui bimbingan keagamaan di Panti Sosial Tresna Werdha Budi Pertiwi Kota Bandung. Dengan agama mereka bisa menyelesaikan berbagai problematika yang menimpa hidup mereka yang membuat hidup mereka menjadi tidak tenang. Semangat mereka dalam mengikuti berbagai macam kegiatan yang ada di Panti Sosial Tresna Werdha Budi Pertiwi benar-benar sangat baik. Terlebih dalam proses bimbingan keagamaan yang ada di Panti Sosial Tresna Werdha Budi Pertiwi benar-benar berhasil dan dapat mengatasi problem psikis lansia.

Hal itu dapat dilihat dari tujuan yang telah di capai, diantaranya adalah: a) para lansia yang tadinya belum bisa membaca Al-Qur'an sedikit-sedikit sudah mulai bisa, b) sebagian para lansia yang sering bertengkar dengan penghuni lansia lainnya, sudah mulai jarang bertengkar dan yang terjadi sekarang mereka lebih menghormati, menghargai dan menyayangi satu dengan yang lainnya, c) para lansia sudah memiliki rasa tanggung jawab sendiri terhadap apa yang menjadi kewajibannya sendiri, seperti melakukan shalat wajib tanpa disuruh dan mengerjakan hal-hal positif, d) sebagian para lansia juga sudah bisa menyelesaikan permasalahannya sendiri. Metode bimbingan Islam ini akan di klasifikasikan berdasarkan segi komunikasi, pengelompokannya menjadi dua macam, yaitu metode langsung dan metode tidak langsung. Kedua metode ini masing-masing mempunyai kelebihan dan kekurangan atas hasil yang dicapainya. (Fakih, 2001: 54-55) 


\section{PENUTUP}

Pertama, keadaan psikis lansia disana kurang baik ditandai dengan sering sakitsakitan, sering bertengkar sesama penghuni, keadaan fisik yang lemah dan tidak berdaya sehingga harus tergantung pada orang lain, sebagian penghuni belum bisa mengaji, kesepian dikarenakan rindu kepada keluarga. Kedua, adapun bimbingan keagamaan yang dilakukan di Panti Sosial Tresna Wredha Budi Pertiwi ini benarbenar berperan penting upaya mengatasi problem psikis lansia. Karena dengan agama mereka saling menghargai dan menghormati antar sesama. Selain itu juga mereka bisa mengendalikan emosi mereka ketika mereka marah ataupun sedih dengan cara banyak berdzikir. Dengan begitu penulis bisa menyimpulkan bahwa bimbingan keagamaan sangat berperan penting bagi lansia untuk upaya mengatasi problem psikisnya.

Ketiga, hasil bimbingan keagamaan dalam upaya mengatasi problem psikis lansia yang dilakukan di Panti Sosial Tresna Wredha Budi Pertiwi ini sangat berperan penting dalam upaya mengatasi problem psikis lansia. Dengan agama mereka bisa menyelesaikan berbagai problem yang menimpa hidup mereka yang membuat hidup mereka tidak tenang. Semangat mereka dalam mengikuti berbagai macam kegiatan yang ada di Panti Sosial Tresna Wredha Budi Pertiwi benar-benar sangat baik. Terlebih dalam proses bimbingan keagamaan yang ada di Panti Sosial Tresna Wredha Budi Pertiwi benar-benar berhasil dan dapat mengatasi problem psikis lansia. Hal itu dapat dilihat dari tujuan yang telah di capai, diantaranya adalah: a) para lansia yang tadinya belum bisa membaca Al-Qur'an sedikit-sedikit sudah mulai bisa, b) sebagian para lansia yang sering bertengkar dengan penghuni lansia lainnya, sudah mulai jarang bertengkar dan yang terjadi sekarang mereka lebih menghormati, menghargai dan menyayangi satu dengan yang lainnya, c) para lansia sudah memiliki rasa tanggung jawab sendiri terhadap apa yang menjadi kewajibannya sendiri, seperti melakukan shalat wajib tanpa disuruh dan mengerjakan hal-hal positif, d) sebagian para lansia juga sudah bisa menyelesaikan permasalahannya sendiri.

\section{DAFTAR PUSTAKA}

A.A Yusuf. 2003. Studi Agama Islam. Bandung: CV Pustaka Setia

Arifin. 1994. Pedoman Pelaksanaan Bimbingan dan Penyuluhan Agama. Golden Terayon Press

Arifin, Isep. "Bimbingan Konseling Islam (al-Irsyad wa al-Tawjîh al-Islam) Berbasis Ilmu Dakwah." Ilmu Dakwah: Academic Journal for Homiletic Studies [Online], 4.11 (2008): 27-42. Web. 25 Aug. 2018

Faqih. A. R. 2001. Bimbingan dan Konseling dalam Islam. Yogyakarta: UII Press

Hawari, Dadang.1999. Al-Qur'an Ilmu Kedokteran Jiwa dan Kesehatan Jiwa. Yogyakarta: Dana Bhakti Prima Yasa Jalaluddin. 2007. Psikologi Agama. Jakarta: PT Raja Grafindo Persada 
Saepah., A. Kusnawan., H. Tajiri.

Kafie, Jamaluddin. 1993. Psikologi Agama. Surabaya: Indah

Lexy. J. Moleong. 2002. Metodologi Penelitian Kualitatif. Bandung: Remaja Rosdakarya

Mujieb, Abdul. 1994. Kamus Istilah Fiqih. Jakarta: PT Pustaka Firdaus

Nirmala. 2002. Jadilah Lanisa Sehat Sejahtera, Mandiri, Produktif. Jakarta: Narya Gunatra

Sarwono. S. Wirawan. 2000. Pengantar Umum Psikologi. Jakarta: Bulan Bintang

Surawan Martinus. 2008. Kamus Kata Serapan. Jakarta: PT Gramedia Pustaka Utama

Syah, Muhibbin. 2001. Psikologi Pendidikan dengan Pendekatan Baru. Bandung: Remaja Rosdakarya

Tim Penyusun. 2008. Kamus Besar Bahasa Indonesia edisi ke tiga. Jakarta: Balai Pustaka

Walgito, Bimo. 2010. Bimbingan dan Konseling (studi \& karier). Yogyakarta: CV Andi Offset 